\title{
Electrostimulation, response of the pelvic floor muscles, and urinary incontinence in elderly patients post prostatectomy
}

\author{
Eletroestimulação, resposta dos músculos do assoalho pélvico \\ e incontinência urinária em pós-prostatectomizados
}

\author{
Patrícia Zaidan $^{[\mathrm{a}]}$, Elirez Bezerra da Silva ${ }^{[\mathrm{b}]}$
}

[a] Specialist in Urogynecological Physical Therapy, University Gama Filho (UGF - RJ), collaborator physical therapist of the Outpatient Urogynecologic Physical Therapy of Hospital dos Servidores do Estado do Rio de Janeiro, Rio de Janeiro, RJ Brazil, e-mail: patriciazaidan@gmail.com

[b] PhD in Physical Education, University Gama Filho (UGF - RJ), coordinator of Post-Graduation Course in Physical Therapy (UGF), professor of the Post-Graduation stricto sensu Program in Sciences of the Exercise and Sports (UGF), coordinator of the Research Group Clinical School (UGF), Rio de Janeiro, RJ - Brazil, e-mail: elirezsilva@cosmevelho.com.br

\begin{abstract}
Objective: to investigate the response of the pelvic floor muscles (PFM), and urinary incontinence (UI), in patients having undergone a prostatectomy, after treatment using electrical stimulation. Materials and methods: this observational study was conducted in an outpatient urogynecologic physical therapy clinic of Hospital dos Servidores in Rio de Janeiro, Brazil from August to September 2012. Ten patients (aged, $64 \pm$ 7 years) with urinary incontinence resulting from radical prostatectomy, having received surgery within six months of study entry, without urinary infection, and without metallic implants underwent electrical stimulation of the PFM, while in lateral decubitus position with knees and hips flexed. The parameters used were $65 \mathrm{~Hz}$ frequency, pulse width of $500 \mu \mathrm{s}$, biphasic current, intensity according to the tolerance level reported by the patient, perineal contraction time of four seconds, and rest time of eight seconds for 20 minutes twice a week, totaling 16 sessions of electrical stimulation with active-assisted contraction. Patients were evaluated before and after electrical stimulation through physical therapy evaluation of urinary incontinence, by being asked about the number of disposable guards used daily, using a visual analogue scale (VAS) to measure how the UI interfered with activities of daily living, and by electromyographic biofeedback to measure the work of the PFM. Data were analyzed using Student's paired t-tests and a significance level of 0.05. Results: after 16 sessions of electrical stimulation, the electromyographic biofeedback evaluation showed a significant
\end{abstract}


increase in muscle strength of $10.73 \pm 8.64$ to $17.16 \pm 9.00 \mu \mathrm{V}(\mathrm{t}=-3.39, \mathrm{P}=0.008)$, a significant decrease in the number of diapers used before and after treatment $(3.9 \pm 1.2$ to $1.8 \pm 1.5$, respectively; $t=5.16, P=$ 0.0006), and a significant decrease in the interference of urinary incontinence on daily activities of $9.6 \pm 0.5$ to $4.0 \pm 3.8(\mathrm{t}=5.15, \mathrm{P}=0.0006)$. Conclusion: electrical stimulation may represent a novel way to strengthen the pelvic floor muscles and decrease urinary incontinence resulting from radical prostatectomy.

Keywords: Urinary incontinence. Prostatectomy. Electric stimulation.

\section{Resumo}

Objetivo: verificar a resposta dos músculos do assoalho pélvico (MAP) e da incontinência urinária (IU) em homens prostatectomizados após o uso da eletroestimulação como tratamento. Materiais e métodos: estudo observacional, realizado no ambulatório de fisioterapia uroginecológica do Hospital dos Servidores do Estado do Rio de Janeiro, no período de agosto a setembro de 2012. Dez pacientes com $64 \pm 7$ anos de idade, com incontinência urinária pós-prostatectomia radical, tempo máximo após cirúrgia de seis meses, sem infecção urinária e sem implante metálico foram submetidos à eletroestimulação dos MAP, que consistiu de um eletrodo endoanal (Dualpex 961 - Quark), com paciente na posição de decúbito lateral com joelhos e quadril flexionados. Os parâmetros utilizados foram frequência de $65 \mathrm{~Hz}$, largura de pulso de 500 ps, corrente bifásica, intensidade de acordo com o nível de tolerância relatada pelo paciente, tempo de contração perineal de quatro segundos e tempo de repouso de oito segundos, durante 20 minutos, duas vezes semanais, totalizando 16 sessões de eletroestimulação com contração ativa-assistida. Os pacientes foram avaliados antes e após a eletroestimulação por meio de relato sobre os ítens da avaliação fisioterapêutica da incontinência urinária, questionados sobre o número de protetores descartáveis utilizados diariamente, submetidos à escala visual analógica (EVA) para medir o quanto a IU interferia em suas atividades de vida diárias e ao biofeedback eletromiográfico para medir o trabalho dos MAP. Os dados foram analisados pelos teste $t$ - student para amostras pareadas, para um nível de significância de 0,05. Resultados: após as 16 sessões de eletroestimulação a avaliação pelo biofeedback eletromiográfico mostrou um aumento significativo da força muscular de 10,73 \pm 8,64 para 17,16 \pm 9,00 $\mu \mathrm{V}$ ( $t=-3,39 ; P=0,008)$, uma diminuição significativa do número de fraldas usadas antes e após o tratamento de $3,9 \pm 1,2$ para 1,8 $\pm 1,5(t=5,16 ; P=0,0006)$, respectivamente e diminuição significativa da interferência da incontinência urinária nas atividades diárias de $9,6 \pm 0,5$ para 4,0 $\pm 3,8(t=5,15 ; P=0,0006)$. Conclusão: a eletroestimulação pode ser uma forma de reforçar a musculatura do assoalho pélvico e diminuir a incontinência urinária decorrente da pós-prostatectomia radical.

Palavras-chave: Incontinência urinária. Prostatectomia. Estimulação elétrica.

\section{Introduction}

The prevalence of prostate cancer has been steadily increasing in the recent years, and is a concern for both medical professionals and men in general. There are two main forms of prostate cancer, which may be benign, and are most commonly affecting men aged 50 and above (1). In Brazil, prostate cancer is one of the most common malignancies affecting men, with an estimated 60,180 new cases of prostate cancer diagnosed in 2012, according to the Brazilian National Institute of Cancer (INCA). In 2009, prostate cancer was responsible for 12,274 deaths (2). Radical prostatectomy is a common treatment option for localized prostate cancer. Despite being highly effective, the procedure is associated with a number of issues such as bladder, intestinal, and sexual dysfunction due to complications of the surgery (3).

Urinary incontinence (UI) depends on the integrity of the internal and external sphincters, in addition to the prostatic and membranous urethral segments. In turn, the function of the external sphincter is dependent on the proper functioning of its striated muscle fibers (4). Despite recent improvements in surgical techniques, urinary incontinence due to prostatectomy is still a relatively common issue, 
affecting between 6 and $63 \%$ of men $\geq 6$ months after surgery $(5,6)$.

After radical prostatectomy, urinary incontinence may ensue due to anatomical lesions, making the urethrovesical junction less favorable for maintaining urinary continence, thus generating greater pressure on the external urethral sphincter (7). Recent advances in non-surgical treatments for urinary incontinence have yielded promising results, with a low rate of side effects, and reduced costs (8).

In patients subjected to radical prostatectomy, postoperative urinary incontinence can have a significant effect on their quality of life. Over the last few years, many preventive measures have been described to decrease the risk of urinary incontinence after performing this surgery, including preoperative physiotherapy. Patients with urinary incontinence due to vesical instability are good candidates for physical therapy, and usually acquire continence within one year after surgery. However, patients who have persistent urinary incontinence are more difficult to treat (9). Although urinary incontinence does not put peoples' lives at risk per se, it can have serious medical, social, psychological, and economic implications, thereby adversely affecting the quality of life of the patients (10).

One of the main goals of urogynecological physical therapy is to strengthen the pelvic floor muscles, thereby normalizing the function of these muscles and promoting their conscious and effective contractions in moments of increased intra-abdominal pressure, which prevents involuntary urinary leaks (11). Besides strengthening of the pelvic floor muscle group by kinesiotherapy, physical therapeutic intervention in this condition can also comprise of biofeedback and functional electrical stimulation (12), and physical therapy is another therapeutic resource that uses efficient physical modalities in the treatment of this pathology (13). Electrical stimulation has shown promising results for the treatment of UI, as it is able to re-educate the muscles of the pelvic floor. However, for it to achieve optimal results, it should be used in association with other conservative treatment methods (13). Electrical stimulation offers muscle gain through cutaneous or endoanal devices, which works by promoting an increase in sphincter resistance and reductions in the contraction of detrusor muscle (14), Treatment with electrical stimulation has been shown to increase the success of exercises for pelvic muscles in patients with urinary incontinence after radical prostatectomy (6). Furthermore, treatment with biofeedback aims to promote an effective bladder emptying, as well as an appropriate continence, and to identify, locate, and ensure the muscle proprioception to achieve muscle coordination and rehabilitation, thus eliminating inadequate patterns of contractions (15).

The evaluation of the pelvic floor performed by electromyographic biofeedback is reproducible, and consistently predicts the clinical variables related to the functioning of these muscles. Electromyographic biofeedback is the method used to measure the muscle electrical activity, which is achieved by using an electrode capable of measuring spontaneous or voluntary activity of motor units (16).

The aim of this study was to determine the response of the pelvic floor muscles and potential changes in urinary incontinence status in prostatectomized men submitted to electric stimulation.

\section{Materials and methods}

Sample

Ten patients (mean age, $64 \pm 7$ years old), who were evaluated for urinary incontinence post-radical prostatectomy who were within six months of their surgery, and who did not suffer urinary infection or had metallic implants, were enrolled in the study and followed at the outpatient Urogynecologic Physical Therapy Clinic of Hospital dos Servidores in the State of Rio de Janeiro (HFSE), Brazil from August to September 2012.

All volunteers signed a consent form authorizing the use of their information for research purposes. The authors received formal authorization from the head of the outpatient Urogynecology for the implementation of this study. This study followed the rules of Resolution CNS196/96, and was approved by the Ethics and Research Committee of the University Gama Filho (protocol number 05119012.0.0000.5287).

\section{Electrical activity of the pelvic floor}

The electromyographic biofeedback Miotool-uro $\left(\right.$ Miotec $^{\circledR}$ ), was used to measure the electrical activity of the pelvic floor, before and after treatment. The 
evaluation mode was selected and all parameters were set to zero. We used an endoanal electrode, a surface electrode positioned over the sternum for reference, and two surface electrodes positioned on the infraumbilical region and rectus abdominis muscle bilaterally, aiming to control the relaxation of this muscle group. All electrodes were calibrated and coupled to a computer. The electrical activity of the pelvic floor was recorded graphically and numerically on the computer, upon verbal request to the patient, in the lateral position, to perform a maximal voluntary contraction of the external anal sphincter muscle for three seconds.

\section{Urinary incontinence}

Urinary incontinence was measured by its interference in daily life using a Visual Analogue Scale (VAS) (17) and questioning about the number of disposable protectors used daily, before and after treatment. In the implementation of VAS, the patient chose a score from 0 to 10 , where 0 corresponds to "does not interfere" and 10 corresponds to "interferes a lot".

Below is the VAS model used in the study:

Visual Analogue Scale (VAS)

In general, to what level does urinary incontinence interfere with your everyday life?

Please, circle a number between 0 (does not interfere) to 10 (interferes a lot)

Does not interfere 012345678910 interferes a lot

\section{Endoanal electrostimulation}

Patients underwent electrical stimulation using an endoanal electrode (Dualpex 961 - Quark $^{\circledR}$ ) in the lateral position with knees and hips flexed according to patient comfort. The parameters used were frequency of $65 \mathrm{~Hz}$, pulse width of $500 \mu \mathrm{s}$, biphasic current, intensity according to the level of tolerance reported by the patient, perineal contraction time of 4 seconds and rest periods of 8 seconds, for 20 minutes 2 times weekly, totaling 16 sessions of electrical stimulation with active-assisted contractions.

\section{Data analysis}

The results are presented as means \pm standard deviation $(\overline{\mathrm{x}} \pm \mathrm{SD})$. Paired Student's t-tests, with a significance level of $\mathrm{P}<0.05$, were used to test our hypothesis that increased electrical activity of the pelvic floor results in decreased interference of urinary incontinence on daily life and in a reduction in the amount of disposable protectors used. All analyses were performed using Statistica 6.0 (Statsoft ${ }^{\circledR}$, Inc, 1984-2001) software.

\section{Results and discussion}

Electromyographic evaluation allows for the assessment of muscle electrical activity, enabling the capture of action potentials generated during voluntary contraction of the muscles (18). Besides assessing the ability to contract, the electromyography records the contraction amplitude in microvolts $(\mu \mathrm{V})$, which can be considered as an indirect measure of muscular strength (19).

The results obtained (Table 1 ) in this study showed a significant increase of $59 \%$ in the electrical activity of the pelvic floor muscles ( $\mathrm{P}=0.008)$ (Figure 1 ), significant reductions of $54 \%$ in the number of diapers used $(\mathrm{P}=0.0006)$ (Figure 3$)$, and of $58 \%$ in the interference of urinary incontinence on daily activities ( $\mathrm{P}=0.0006)$ (Figure 2$)$, after 16 sessions of electrostimulation. The effect size of the electrical activity of the pelvic floor muscles was 0.74 , the effect size of the interference of urinary incontinence in daily life was 11.2, and the effect size of used disposable protectors was 1.75. In general, the results were considered satisfactory.

Electrical stimulation is recognized as a fundamental therapy for reeducation of the sphincter and perineum, and works by promoting muscle contraction and allowing the patients to become aware of themselves (20). In this study, the recruitment of larger motor units (fast fibers) more likely to hypertrophy were favored, which, in voluntary contractions, are difficult to recruit $(21,22)$. Another advantage of the electrical stimulation was inhibition of fatigue of the central nervous system, due to 
Table 1 - Mean and standard deviations of the electrical activity of the pelvic floor (EAPF), interference with daily life (IDL), and amount of disposable protectors used before and after 16 sessions of endoanal electrostimulation

\begin{tabular}{lrr}
\hline Factor & \multicolumn{2}{c}{ Endoanal electrostimulation } \\
\hline & \multicolumn{1}{c}{ Pre } & \multicolumn{1}{c}{ Post } \\
\cline { 2 - 3 } EAPF $(\mu \mathrm{V})$ & $10.7 \pm 8.6$ & $17.2 \pm 9.0^{*}$ \\
IDL & $9.6 \pm 0.5$ & $4.0 \pm 3.8^{*}$ \\
Disposable protectors & $3.9 \pm 1.2$ & $1.8 \pm 1.5^{*}$ \\
\hline
\end{tabular}

Note: *: $\mathrm{P}<0.05$ regarding the pre-treatment values.

Source: Research data.

simulation of the passage of nerve impulses, which subsequently led to muscle contractions without the need for an impulse from the nervous system itself. This made possible a higher number of repetitions and therefore a higher muscular work, apart from enabling an isolated training (23). This was due to the fact that electrical stimulation evokes action potentials in axons of alpha motoneurons, which are found in the peripheral nerves, allowing the contraction of skeletal muscles (24). We here found that electrical stimulation was a very useful complementary method of strength training, which increased not only the maximum stimulated strength, but also the voluntary strength, speed of movement, and muscle endurance (25). In this study we used electrostimulation with active-assisted contraction as a way to strengthen the pelvic floor muscles, which, according to literature, allows the predominant recruitment of rapid fibers, since they are more superficial, where the electric current arrives more efficiently, which would take place with voluntary contraction if training was only between $70 \%$ and $90 \%$ of the maximum load, thus activating all the slow fibers and most of the rapid fibers. The electrostimulation treatment performed in this study proved to be effective in recruiting both fast and slow fibers, hence allowing prompt and efficient rehabilitation of the pelvic floor muscles $(22,26)$.

Urinary incontinence can be associated with more psychosocial devastating effects than health consequences per se, with multiple, and often comprehensive, effects that can influence everyday activities, social interactions, and the self-perceived health status (27). In the present study, the significant reduction in the use of diapers to contain the daily urine of $3.9 \pm 1.2$ to $1.8 \pm 1.5(\mathrm{t}=5.16$; $\mathrm{P}=$
$0.0006)$ likely contributed to the significant decrease observed in the interference of urinary incontinence on the daily lives of people from $9.6 \pm 0.5$ to $4.0 \pm 3.8$ $(\mathrm{t}=5.15 ; \mathrm{P}=0.0006)$.

The studies of Ribeiro et al. (28), Moore et al. (6), Salinas et al. (29), Bales et al. (5), reinforce the results found in this study. Ribeiro et al. conducted a randomized clinical trial to evaluate the efficiency of biofeedback in pelvic floor muscle training for the treatment of urinary incontinence in prostatectomized men. A total of 73 patients were randomized into either a treatment group receiving biofeedback training of pelvic floor muscle once a week for 3 months, as well as home exercises $(n=36)$, or a control group $(n=37)$ who did not receive formal education in training of the pelvic floor muscles. They were given brief verbal instructions by the urologist to contract the pelvic floor muscle, or were recommended a specific exercise program. At 12 months post-surgery, $96.15 \%$ of the participants from the treatment group, and $75 \%$ of the participants from the control group were continent $(P=0.028)$, with the duration of incontinence being lower (1 month) for the treatment group than for the control group (6 months). These results indicate that strength training of the pelvic floor muscles with biofeedback can accelerate the recovery of urinary continence after radical prostatectomy within 12 months post-surgery (28).

Moore et al. randomized 63 participants to evaluate the effectiveness of electrical stimulation with or without muscle exercises for the pelvic floor, to treat urinary incontinence in post radical prostatectomy. In 12 weeks, the average loss of urine decreased from $463 \mathrm{~g}$ to $115 \mathrm{~g}$ in their study, but there were no differences between the groups, or significant differences in urine loss at 16 and 24 weeks $(\mathrm{F}=0.16$; 
$P=0.69$ ). Similar to our findings, urinary incontinence had a significant impact on the lives of the patients after radical prostatectomy. Quality of life was one of the outcomes measured in this study, as assessed by questionnaires IIQ-7 and EORTC QLQ C-30, and the authors reported a significant improvement in urinary incontinence in patients assigned to the intervention group (exercises for the pelvic floor muscles associated with electrical stimulation) (29).

Salinas et al. (29) conducted clinical and urodynamic studies with rectal electrical stimulation for urinary incontinence after prostatectomy in 19 patients with urinary incontinence, and obtained poststimulation positive clinical results in $78 \%$ of cases. Thus, they concluded that this intervention was a viable therapeutic alternative for UI (30).

On the other hand, the findings from studies by Bales et al. (5) and Hunter et al. (12) differed from the results of the present study. Bales et al. randomized 100 men in a clinical trial to receive training exercises for the pelvic floor muscles with biofeedback (intervention) or without biofeedback (control), in both the pre- and postoperative stages

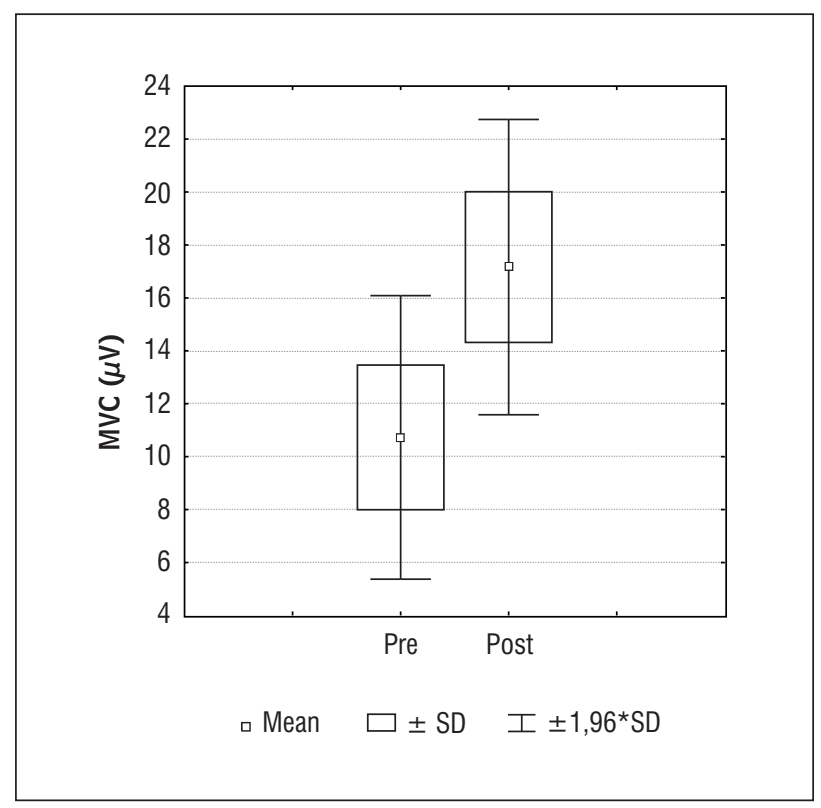

Figure $\mathbf{l}$ - Measurement of maximum voluntary contraction (MVC) by the electrical activity of the pelvic floor $(\mu \mathrm{v}=$ microvolt), before and after 16 sessions of endoanal electrostimulation (Student's paired t-test, - 3.39; $P=0.008$ )

Note: SD: standard deviation.

Source: Research data. of prostatectomy, in order to improve urinary incontinence. Six months after surgery, the continence rates, as defined by the use of one diaper or less per day, were $94 \%$ and $96 \%$ in the biofeedback and control groups, respectively $(\mathrm{P}=0.596)$, suggesting that no improvements were obtained from preoperative biofeedback training (5). However, in that study, patients received both training of the pelvic floor muscles and verbal instructions from nurses, and were evaluated by questionnaires or phone calls, which may have influenced the results.

Finally, a recent systematic review by Hunter et al. (12) evaluated conservative treatment, consisting of training of the pelvic floor muscles with or without biofeedback, electrical stimulation, penile clamps, extracorporeal magnetic innervation, or a combination of these methods, for the treatment of post-prostatectomy urinary incontinence. Although the interventions were not directed to the strengthening of the pelvic muscles, analyses of interventions such as electrical stimulation were inconclusive, and there were few data to determine the effects of treatment on incontinence. Most of these studies showed a low-to-moderate quality (12).

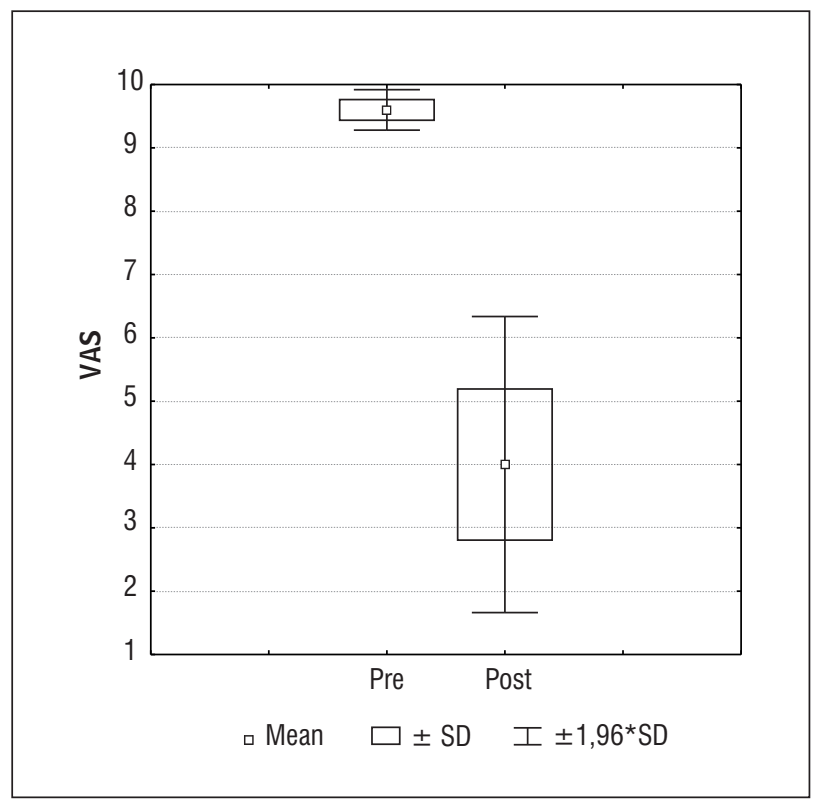

Figure 2 - Measuring of the interference of urinary incontinence in daily life using the visual analogue scale (VAS), before and after 16 sessions of endoanal electrostimulation (Student's paired t-test, 5.15; $P=0.0006)$

Note: SD: standard deviation.

Source: Research data. 


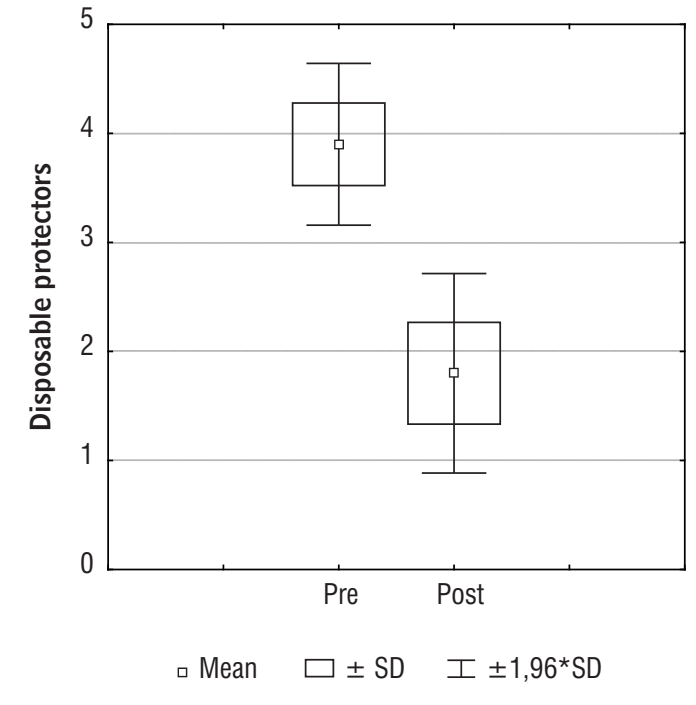

Figure 3 - Amount of disposable protectors used before and after 16 sessions of endoanal electrostimulation (Student's paired t-test, 5.16; $\mathrm{P}=0.0006$ )

Note: SD: standard deviation.

Source: Research data.

\section{Conclusion}

The data obtained in this study indicate that electrostimulation may be a feasible way to strengthen the pelvic floor muscles and decrease urinary incontinence and the associated interference in the daily lives of people having undergone radical prostatectomy.

\section{References}

1. Srougi M. Câncer de próstata: uma opinião médica. Urologia on line. 1998 [cited 2005 Set];2(5). Availabe from: http://www.unifesp.br/dcir/urologia/uroline/ ed1098/tela.htm

2. Ministério da Saúde (Brasil). Instituto Nacional de Câncer José Alencar Gomes da Silva - INCA. Estimativa 2012: incidência de câncer no Brasil. Rio de Janeiro. INCA, 2011 [cited 2014 Feb 21]. Available from: http://portal.saude.sp.gov.br/resources/ses/perfil/ gestor/homepage/estimativas-de-incidencia-de-cancer-2012/estimativas_incidencia_cancer_2012.pdf
3. Petry H, Berry LD, Spichiger E, Kesselring A, Gasser CT, Sulser T, et al. Responses and experiences after radical prostatectomy: perceptions of married couples in Switzerland. Int J Nurs Stud. 2004;41(15):507-13.

4. Kakihara CT, Sens YAS, Ferreira U. Efeito do treinamento funcional do assoalho pélvico associado ou não à eletroestimulação na incontinência urinária após prostatectomia radical. Rev Bras Fisioter. 2007;11(6):481-6.

5. Bales GT, Gerber GS, Minor TX, Mhoon DA, McFarland JM, Kim HL, et al. Effect of preoperative biofeedback/ pelvic floor training on continence in men undergoing radical prostatectomy. Urology. 2000;56(4):627-30.

6. Moore KN, Griffiths D, Hughton A. Urinary incontinence after radical prostatectomy: a randomized controlled trial comparing pelvic muscle exercises with or without electrical stimulation. BJU Int. 1999;83(1):57-65.

7. Johnson TM, Ouslander JG. Urinary incontinence in the older man. Med Clin North Am. 1999;83(5):1247-66.

8. Herrmann V, Potrik BA, Palma PCR, Zanettini CL, Marques A, Netto NR Jr. Eletroestimulação transvaginal do assoalho pélvico no tratamento da incontinência urinária de esforço: avaliações clínica e ultrasonográfica. Rev Assoc Med Bras. 2003;49(4):401-5.

9. Peyromaure M, Ravery V, Boccon-Gibod L. The management of stress urionary incontinence after radical prostatectomy. BJU Int. 2002;90(2):155-61.

10. Lopes MBHM, Higa R. Restrições causadas pela incontinência urinária à vida da mulher. Rev Esc Enferm USP. 2006;40(1):34-41.

11. Rett TM, Simões AJ, Herrmann V, Gurgel CSM, Morais SS. Qualidade de vida em mulheres após tratamento da incontinência urinária de esforço com fisioterapia. Rev Bras Ginecol Obstet. 2007;29(3):134-40.

12. Hunter KF, Glazener CM, Moore KN. Conservative management for post prostatectomy urinary incontinence. Cochrane Database Syst Rev. 2007; 18;(2):CD001843.

13. Bernardes ON, Péres RF, Souza LBLE, Souza LO. Métodos de tratamentos utilizados na incontinência urinária de esforço genuína: um estudo comparativo entre cinesioterapia e eletroestimulação endovaginal. RBGO. 2000;22(1):49-54. 
14. Kubagawa ML, Pellegrini FRJ, Lima PV, Moreno LA. A eficácia do tratamento fisioterapêutico da incontinência urinária masculina após prostatectomia. Rev Bras Cancerol. 2006;52(2):179-83.

15. Saieh C, Escala MJ, Freundlich O. Incontinência urinaria: nuevo tratamiento Biofeedback. Rev Med Clin Condes. 2000;11(3):111-2.

16. Nagib LBA, Guirro OCE, Palauro AV, Guirro JRR. Avaliação da sinergia da musculatura abdomino-pélvica em nulíparas com eletromiografia e biofeedback perineal. Rev Bras Ginecol Obstet. 2005;27(4):210-5.

17. Pavan K, Miguez BP, Marangoni MEB, Tilbery PC, Lianza S. Comportamento da incontinência urinária em pacientes com esclerose múltipla e a sua influência na qualidade de vida. Med Reabil. 2010;29(1):1-5.

18. Rahal A, Gomez GSVM. Avaliação eletromiográfica do músculo masseter em pessoas com paralisia facial periférica de longa duração. Rev CEFAC. 2007;9(2):207-12.

19. Muchailh CR. Importância da eletromiografia na avaliação funcional da musculatura do assoalho pélvico em mulheres nulíparas continentes [dissertação]. São Paulo: Universidade Estadual Paulista; 2008.

20. Moreno LA. Fisioterapia em Uroginecologia. São Paulo: Manole; 2009.

21. Stein RB, Chong SL, James KB, Kido A, Bell GJ, Tubman LA, et al. Electrical stimulation for therapy and mobility after spinal cord injury. Prog Brain Res. 2002;137:27-34.

22. Zatsiorsky VM. Ciência e prática do treinamento de força. São Paulo: Phorte; 1999.
23. Weineck J. Biologia do esporte. São Paulo: Manole; 1991.

24. Robinson AJ, Mackler LS. Eletrofisiologia clínica. 3. ed. Porto Alegre: Artmed; 2010.

25. Fleck SJ, Kraemer WJ. Designing resistance training programs. Champaign: Human Kinetics; 1997.

26. Costa MG. Ginástica localizada. Rio de Janeiro: Sprint; 1998.

27. Ramos BHS, Donadel KF, Passos TS. Reabilitação da musculatura pélvica aplicada ao tratamento da incontinência urinária. Rev Conquer. 2006;1(11).

28. Ribeiro LH, Prota C, Gomes CM, de Bessa J Jr., Boldarine MP, Dall'Ogglio MF, et al. Long-term effect of early postoperative pelvic floor biofeedback on continence in men undergoing radical prostatectomy: a prospective, randomized, controlled trial. J Urol. 2010;184(3):1034-9.

29. Casado JS, Chamorro MV, Mohamed SS, de Rueda CB, Aristizábal JM, Estévez LR. Results of electric stimulation in the treatment of post-prostatectomy urinary incontinence. Actas Urol Esp. 1996;20(6):544-50.

Received: 04/17/2013 Recebido: 17/04/2013

Approved: $12 / 15 / 2013$ Aprovado: 15/12/2013 